\title{
Leuko-Araiosis: An Ancient Term for a New Problem
}

\author{
V.C. Hachinski, P. Potter and H. Merskey
}

\begin{abstract}
Recent research with computerized tomography (CT) and magnetic resonance imaging (MR) of the brain has revealed a type of tissue change for which no fitting term exists. The change appears as areas of decreased density on CT and changed signals of the white matter in MR images. Because neither a definite pathological change nor a specific clinical deficit has been linked with the CT and MR changes, a designation is required that limits itself to describing the changes themselves.

We propose "leuko-araiosis". The Greek root leuko-, signifying "white", has found wide usage in modern medical terminology: e.g. leucine, leukocyte, leukorrhoea. Also several precedents exist for its application to the white matter of the central nervous system: e.g. leukoencephalitis, leukomyelitis, leukotomy. Araios is an adjective meaning "rarefied", and the suffix -osis converts the adjective to a noun meaning "rarefaction, diminution of density", a word used in the Hippocratic Collection to describe a state of excessive porosity of the lung.
\end{abstract}

A descriptive term precludes premature presuppositions and encourages the search for causes.

RÉSUMÉ: Leuko-araiosis: un terme ancien pour désigner un problème nouveau. Des recherches récentes au moyen de la tomographie assistée par ordinateur (TAO) et de l'imagerie par résonance magnétique nucléaire (IRMN) ont mis en évidence, dans le cerveau, un type de modification tissulaire pour lequel il n'existe aucun terme approprié. Le changement se présente à la TAO sous forme d'aires de densité réduite et à l'IRMN, sous forme de signaux altérés provenent de la substance blanche. Comme aucun changement pathologique précis et aucun déficit clinique spécifique n'a été relié aux changements présents à la TAO et à l'IRMN, il est nécessaire de désigner ces changements par un terme qui se limite à décrire les changements eux-mêmes.

Nous proposons le terme "leuco-araiosis". La racine grecque leuco-, qui veut dire blanc, est couramment utilisée dans la terminologie médicale moderne: e.g. leucine, leucocyte, leurcorrhée. Il existe également plusieurs précédents en ce qui a trait à son utilisation pour désigner la substance blanche du système nerveux central: e.g. leucoencéphalite, leucomyélite, leucotomie. Araios est un adjectif qui veut dire "raréfié" et le suffix -osis transforme l'adjectif et un nom qui veut dire "raréfaction, diminution de la densité". Ce mot est utilisé dans la Collection Hippocratique pour décrire un état de porosité excessive au niveau des poumons.

Un terme descriptif tend à prévenir les présuppositions hâtives et à encourager la recherche des causes du phénomène.

Can. J. Neurol. Sci. 1986; 13:533-534

\section{An Apparent Paradox}

Although the world literature contains fewer than 50 cases of pathologically verified Binswanger's disease, recent reports of computerized tomography (CT) and magnetic resonance (MR) series $^{1,2}$ report dozens of cases labelled as such.

This apparent epidemic is occurring at a time when hypertension, the hallmark of Binswanger's disease, is coming under increasing control. Moreover, only some of the patients who display hypodensities on CT or changed signals on MR are hypertensive. It is improbable that these radiological findings represent Binswanger's disease. It is more likely that we are witnessing the unfounded attribution of a specific pathological etiology to increasingly more sensitive images of the brain.

\section{Radiological Images and Reality}

Although white matter changes on $\mathrm{CT}$ and MR images have been lumped under the same etiological label, the intense white matter signal ringing the ventricles on MR images ${ }^{2}$ may bear little relationship on the irregular white matter hypodensities sometimes seen on CT scanning. ${ }^{3}$ Symmetrical periventricular white matter change may represent the penetration of cerebrospinal fluid into shrinking brain, producing pallor and the appearance of edema at autopsy. ${ }^{4}$ On the other hand, the asymmetric patchy and more intense changes may represent a confluence of micro-infarcts from hypertension or cerebral amyloid angiopathy, or both. At times, an ischemic axonopathy may be responsible for the white matter appearance. ${ }^{5} \mathrm{~A}$ number of

From the Department of Clinical Neurological Sciences, University Hospital, London, Ontario (Dr. Hachinski); the Department of History of Medicine and Science, University of Western Ontario, London, Ontario (Dr. Potter); and the Department of Education and Research, London Psychiatric Hospital, London, Ontario (Dr. Merskey)

Reprint requests to: Dr. V. Hachinski, Department of Clinical Neurological Sciences, University Hospital, 339 Windermere Road, London, Ontario, Canada N6G 2K3 
other factors may contribute to changes in white matter appearance on CT and MR. Aging is associated with changes in cerebral myelin. ${ }^{6}$ Grey matter degeneration may produce secondary changes in white matter although severe grey matter involvement is associated with only mild myelin loss. ${ }^{7}$ Moreover, entities may interact or coexist. We need a neutral term, precise enough to define white matter changes in the elderly or the demented, general enough that it serves as a description and a label, and demanding enough that it calls for a precise clinical and imaging description accompanied when possible by pathological verification.

\section{A Descriptive Term}

The common denominator of white matter changes in elderly or demented individuals is decreased density on CT or a change in the bound hydrogen signal on MR. We therefore suggest the term "leuko-araiosis" meaning a diminution of the density of representation of the white matter.

The Greek root leuko-signifying "white" has found wide and varied usage in modern scientific and medical terminology: e.g. leucine, leukoplakia, leukocyte, leukorrhoea. Several precedents exist for its application to the white matter of the central nervous system: e.g. leuk(o)encephalitis, leukodystrophy, leukomyelitis, leukotomy.

Two different patterns of usage reveal themselves:

i) where that which is white is expressed: e.g. leukocyte, leukodermia;

ii) where what is white is not stated, but is subsumed within leuko-: e.g. leukaemia (for leukocytaemia).

It is the second usage which would apply in the word we are proposing: leuko-stands for "white matter of the brain", exactly as in leukotomy.

Araios is a Greek adjective meaning "rarefied, with its units far apart"; its opposite, pyknos, means "dense, with its units close together". Arios can qualify both space: "of loose texture", and time: "infrequent, intermittent".

The suffix -osis creates a noun with the meaning "the action or process of". Thus araiosis corresponds to the English noun "rarefaction", which the Oxford English Dictionary defines as "the action of rarefying or process of being rarefied; diminution of density",
"Araiosis" occurs twice in the Hippocratic Collection, once referring to the decreased density of the body in old age, and once describing the rarefied character of normal lung substance.

In full agreement with the trend prevailing for nearly a century in English usage to prefer Greek spellings to their latinized equivalents, we have favoured "leuko-" over "leuco" and "araiosis" over "araeosis". As did Freud in his psychoanalysis, we have chosen to retain the final vowel of the first root, where it might have been dropped, in order clearly to mark the division between the roots: leukoaraiosis, not leuk-araiosis.

If leuko-araiosis comes into use as a term obliging precise description, it will ultimately become obsolete as phenomenology gives way to understanding.

\section{ACKNOWLEDGEMENTS}

This study was supported in part by grants from the U.S. National Institure of Health (1R01 AGNS 03047), the Medical Research Council of Canada (PG/21) and the National Health Research and Development Program of the Department of Health and Welfare Canada (\#66062889-44). We thank all the members of the U.W.O. Dementia Group for their support and encouragement.

\section{REFERENCES}

1. Goto K, Ishii N, Fukasawa H. Diffuse white-matter disease in the geriatric population. Radiology 1981; 141: 687-695.

2. Kinkel WR, Jacobs L, Polachini 1, et al. Subcortical arteriosclerotic encephalopathy (Binswanger's disease). Arch Neurol 185; 42: 951-959.

3. Loizou, LA, Kendall BE, Marshall J. Subcortical arteriosclerotic encephalopathy: a clinical and radiological investigation. J Neurol Neurosurg Psychiatry 1981; 44: 294-304.

4. Huang K, Wu L, Luo Y. Progressive subcortical encephalopathy multi-infarct dementia? Can J Neurol Sci $185 ; 12: 88-94$.

5. Ball MJ, Fox AJ, Hachinski VC, et al. Ischemic axonopathy: a pathogenetic mechanism to explain the white matter lucencies in some patients with dementia of the Alzheimer type. Cdn Assoc of Neuropathologists 1986; to be published.

6. Malone MJ, Szoke MC. Neurological changes in white matter: aged human brain and Alzheimer's disease. Arch Neurol 1985; 42: 1063-1066.

7. Brun A, Englund E. A white matter disorder in dementia of the Alzheimer type: a pathoanatomical study. Ann Neurol 1986; 19: 253-262. 